\title{
COVID-19: Recent advances in epidemiology, virology, etiopathogenesis, clinical trials and vaccine development
}

\author{
Banerjee $\mathrm{I}^{1 *}$, Mohabeer $\mathrm{P}^{2}$, Shukla $\mathrm{A}^{3}$, Kashyap $\mathrm{A}^{4}$, Robinson $\mathrm{J}^{5}$
}

*Corresponding author:

Dr. Indrajit Banerjee

Associate Professor, Department of Pharmacology, Sir Seewoosagur Ramgoolam Medical College, Mauritius

Email: indrajit18@gmail.com ORCID

\section{Information about the article:}

Received: May 23, 2020

Accepted: June 24, 2020

Published online: June 30, 2020

Cite this article:

Banerjee I, Mohabeer P, Shukla A, Kashyap A, Robinson J. COVID-19: Recent advances in epidemiology, virology, etiopathogenesis, clinical trials and vaccine development. Journal of Biomedical Sciences. 2020;7(1):18-27

\section{Publisher}

Nepal Health Research Society, Bahundhara -6, Gokarnesowor Municipality, Kathmandu, Nepal eISSN 2382-5545, ISSN 2676-1343 (Print)

(C) The Author(s). 2020

Content licensing: CC BY 4.0

\section{ABSTRACT}

Background

The causative virus of COVID-19 has been named SARS$\mathrm{CoV}-2$. It is the seventh coronavirus that is pathogenic to humans and the third in the series of human pathogenic beta coronaviruses. Patient zero was identified to have contracted the virus in Wuhan, China. Shortly after the initial identification of the virus and its symptoms, multiple studies concluded that the virus originated from the "Wuhan seafood market", a notorious market place for illegal wildlife trade based in Wuhan, a city in the Hubei region of the People's Republic of China. Globally, as of 7:02 pm CEST, 29 May 2020, there have been 5704736 confirmed cases of COVID-19, including 357736 deaths, reported to the WHO. The transmission of COVID-19 is primarily by way of respiratory droplets, which can be developed via means of coughing or sneezing, hence spreading the disease from one person to another person. The research proposed indicates the possibility of bats as being the natural cistern of SARS-CoV-2, hence making COVID-19 a zoonotic disease. The most suspected intermediate host is the Malayan pangolin. SARS-CoV-2 is a single-stranded RNA virus that has an affinity for ACE2 receptors in humans, causing severe pathological symptoms. Symptoms like anorexia, dyspnea, fatigue, pyrexia, cough, headache, dizziness, nausea, productive sputum, abdominal pain, myalgia, sore throat, diarrhea, and vomiting. Vaccines that are currently in the clinical evaluation are the Adenovirus type 5 vector, mRNA-1273, Inactivated alum, ChAdOx, LNP-mRNA, DNA plasmid vaccine with electroporation and Inactivated vaccines. A Phase III randomized multicountry clinical trial comprising of 100 countries known as "Solidarity" (ISRCTN83971151) has been initiated by the WHO to achieve the unified goal of producing an adequate treatment for COVID-19. The present Solidarity trial focuses on the following drugs: Remdesivir, Lopinavir/Ritonavir with or without interferon beta-1a, Chloroquine, or hydroxychloroquine.

\section{Conclusion}

It is invariably essential to promote research in this field of study and find an appropriate solution to the virus to allow individuals worldwide to lead a secure and healthy life.

Keywords

COVID-19, Clinical trials, SARS-CoV-2, WHO, Vaccines 


\section{Background}

The causative virus of COVID-19 has been named SARSCoV-2. It is the Seventh coronavirus that is pathogenic to humans and the third in the series of human pathogenic beta coronaviruses. The first of the beta coronavirus triad lead to Severe Acute Respiratory Syndrome (SARS) and the second caused Middle East Respiratory Syndrome (MERS). [1]. The first confirmed case of the current novel coronavirus or COVID-19, according to all available reports, data, and press conferences from the Chinese Government, states that the first identified case occurred in the first week of December 2019. Patient zero was identified to have contracted the virus in Wuhan, China [2]. Shortly after the initial identification of the virus and its symptoms, multiple studies concluded that the virus originated from the "Wuhan seafood market", a notorious market place for illegal wildlife trade based in Wuhan, a city in the Hubei region of the People's Republic of China. It was noted that the initial cases of the virus were individuals that either frequented or were in close proximity to the activities of the market [3]. Markets such as the nature of the "Wuhan seafood market" are believed to be the origin of members of the coronavirus strain [4].

\section{Epidemiology}

On January 25, 2020, approximately 45 days after, the first reported case of SARS-CoV-2, the active cases accelerated to a total of 1975 people with 56 confirmed deaths in the People's Republic of China. The first death in mainland China was recorded on January 10, 2020 [5]. Twelve days after the first death of COVID-19, China National Health Commission released a document on January 22, 2020, stating that of the first confirmed 17 deaths to date; 13 were male and four were female. The average age of this cohort being 70 years. These infected individuals presented with a host of upper respiratory tract group of symptoms. The virus has had an astronomical rate of spread, with the first case outside of mainland China being confirmed in Thailand on January 13, 2020 [6]. The first sister cities to Wuhan to be infected were Guangdong and Beijing, and by January 10, 2020, Guangdong had 14 confirmed cases, Beijing had a total of 5 and Wuhan had markedly increased their total to 198 confirmed cases [5]. The WHO on January 30, 2020 announced COVID-19 to be the sixth public health emergency of international concern (PHEIC), and as of February 11, 2020, cases were confirmed in over 28 regions. March 11, 2020, marked a historical and foreboding occasion as the COVID-19 virus was declared a pandemic by the WHO [6]. The transmission rate of the virus is exponential. It took 67 days for the confirmed cases to increase from 1 confirmed case to 100,000 confirmed cases, however over the last 24-hour period from May 29, 2020, to May 30, 2020, 19601 new confirmed cases were reported worldwide [6]. Globally, as of 7:02 pm CEST, May 29, 2020, there have been 5704736 confirmed cases of COVID-19, including 357736 deaths [6]. The virus is now affecting 216 countries, territories, and two conveyances. The WHO has six regions over which it governs. The Americas have a current total of 2816141 confirmed cases with a total of 160505 deaths. Brazil is becoming a hotspot in the South American region, with a total of 411821 current cases and 25598 confirmed deaths. In the last 24hour period alone from May 29, 2020, to May 30, 2020, Brazil recorded 4275 new cases. In the United States of America, the current deaths caused by COVID-19 (over 100000) cause a more significant loss of US lives than the number of fatalities caused by the Vietnam war, 58220. Europe has a current total of 1986921 confirmed cases with a total of 172534 deaths. Asia has a current total of 1083755 confirmed cases, with a total of 29743 deaths. As of May 19, 2020, 1:02 pm CEST, China has had a total of 84547 confirmed COVID-19 cases and 4645 deaths [7].

A total of 219921 cases and 5482 deaths were reported in the South Asian Association for Regional Cooperation (SAARC) group of countries. Afghanistan has reported a sum of 9216 cases and 205 deaths, Bangladesh has a sum of 30205 cases and 432 deaths, Bhutan has 24 cases and 0 current deaths, India has a total of 125149 cases and the death count of 3728 , the Maldives has reported a total of 1274 cases and death count of 4, Pakistan has a total of 52437 cases and count of 1101. Sri Lanka has a total of 1068 cases and has reported nine deaths. Nepal has a current total of 548 cases, with three total deaths. The Ministry of Nepal has reported extraordinary findings stating that the majority of their infected cases fall between the ages of 21 to 30 years. Two hundred seventy-five of their current patients are under the age of 30; this finding contradicts the general convention that this virus affects mainly the elderly [8]. Africa has a current total of 137544 cases, with 3945 deaths [7]. Studies have isolated various risk factors for the contraction of COVID-19. It is imperative for the epidemiology of the virus to be understood to prevent further loss of lives and simultaneously prevent such similar COVID-19 outbreaks in the future [9].

\section{Virology of SARS-CoV-2}

Viral Phylogeny indicated that the COVID-19 virus belongs to subgenus Sarbecovirus [10-12].

However, when compared with SARS-CoV-2, these two precedent viruses, namely SARS and MERS, led to similar but more serious clinical manifestations. This resulting in a higher death rate, yet this novel coronavirus has caused more deaths and infections due its unprecedented transmissibility rate. The basic reproductive number (Ro), if defined in simple terms, is used to gauge the transmission power of disease, and has been recorded as highest for COVID-19 compared to SARS and MERS [13].

Hence, it would not be incorrect to state that the significantly elevated transmission rate of COVID-19 led to its establishment as a pandemic. The elevated transmission rate of COVID-19 could partially be 
attributed to the comparably less severe clinical manifestations, which allows the patient to move about and spread the disease within the community [14].

The transmission of COVID-19 is chiefly via respiratory droplets, which can be developed through coughing or sneezing, hence spreading the virus from one person to another. The possibility of bats as the natural reservoir of SARS-CoV-2 has been suggested by research, hence making COVID-19 a zoonotic disease.

However, in accordance with studies with greater depth, the presence of an intermediate host has been established. This intermediate host mediates the spread of COVID-19 between bats and the terminal host, humans [12]. The most likely intermediate host is the Malayan pangolin [15]. 5.2 days is the average incubation period of COVID-19, and in 12.5 days, the total 95 th percentile of the distribution of the virus was seen [16]. Similar to SARS and MERS, COVID-19 attacks the lungs, eventually resulting in respiratory distress. Their similarity in clinical manifestations can be stemmed from the nonidentical yet similar morphology of the coronaviruses. The SARS-CoV-2 is a minute virus, the diameter of which ranges in nanometers. Interestingly, the positive singlestranded RNA nucleic acid possessed by the coronavirus is the most abundant RNA viral genome [17]. All coronaviruses share a spike glycoprotein layer, which constitutes two subunits, namely S1 and S2 [19].

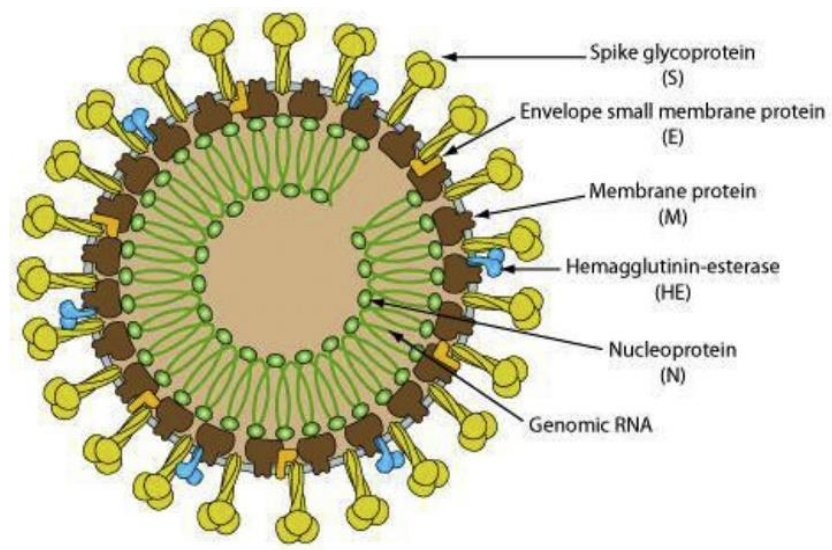

Figure 1: Schematic of a coronavirus

Source: Biowiki

http://ruleof6ix.fieldofscience.com/2012/09/a-newcoronavirus-should-you-care.html [19]

The former mediated adhesion between the SARS-CoV-2 and host cell and the latter enables the fusion of the virus to the host cell membrane. Research has suggested that genetic modification in this layer of the virus could potentially affect the virulence thereof [20]. Moreover, when the coronavirus associated with the pangolin was explored, it was found to be deficient in S1/S2 sites, which are furin-like cleavage sites in the $S$ protein, making it different from that of SARS-CoV-2. This particular finding was suggestive of its increased transmission rate among humans [15]. In addition to this, the coronavirus consists of the integral membrane proteins, specifically Glycoprotein and Small Membrane Protein, ( $\mathrm{M}$ and $\mathrm{E}$ proteins). These are also known as structural proteins. Moreover, Nucleocapsid Protein $(\mathrm{N})$ is a constituent of the virus and is required for its protection [17]. The genes coding for these protein molecules, namely the $\mathrm{N}, \mathrm{E}$, and $\mathrm{S}$ proteins, are identified in the Nucleic Acid Amplification test and hence used to establish the presence of SARS-CoV-2 in specimens for laboratory diagnosis of COVID-19 [21].

The RNA nucleic acid of the coronavirus is made of seven to ten functional genes. Minute variations in the morphology of the different species of the CoV can be attributed to the distinct arrangement of the genes coding for the non-structural proteins in between the functional genes [17]. The knowledge of the viral genome is essential for genomic sequencing of the virus, which has been isolated from specimens of COVID-19 patients, in order to study any possible mutations or used for future research [21]. Interestingly, the RNA-dependent RNA polymerase (RdRp) gene present in SARS-CoV-2 was phylogenetically different as compared to that in SARSCoV [10]. COVID-19 virus also consists of proteins like 3- chymotrypsin-like protease, papain-like protease, and others [19]. The third member of the coronavirus family (COVID-19) continues to exert its virulent impact globally [21].

\section{Etiopathogenesis}

Apart from six other distinctive beta coronaviruses that were pathogenic to humans, the SARS-CoV-2 virus also harmonizes with this group [22]. Due to the pandemic potential of SARS-CoV-2, it is imperative to monitor its transmission and pathogenesis [23].

SARS-CoV-2 is a single-stranded RNA virus that has an affinity for ACE2 receptors in humans, causing severe pathological symptoms. ACE2 is widely expressed in the kidney, stomach, urinary bladder, lung alveolar epithelium, ileum, nasal mucosa, heart, therefore, making all these organs susceptible to SARS-CoV-2 virus. SARSCoV-2 infection is comprehensively transmitted through respiratory droplets, contact, potentially through the fecaloral route and via the ocular surface [24]. It is assumed that the initial viral replication occurs in the mucosa's epithelium in the Upper respiratory tract, which later moves into the Lower Respiratory tract and, finally, the mucosa of the gastrointestinal system.

The elevated levels of proinflammatory cytokines Interleukin1- $\beta$, interleukin 1RA, interleukin 7, interleukin 8 , interleukin 9, interleukin 10, Granulocyte-colony stimulating factor, GMCSF, Interferon $\gamma$, IP10, MCP1, MIP1 $\alpha$, MIP1 $\beta$, PDGFB, and Tumor Necrosis Factor $\alpha$ are seen in patients with SARS-CoV-2 infection. 


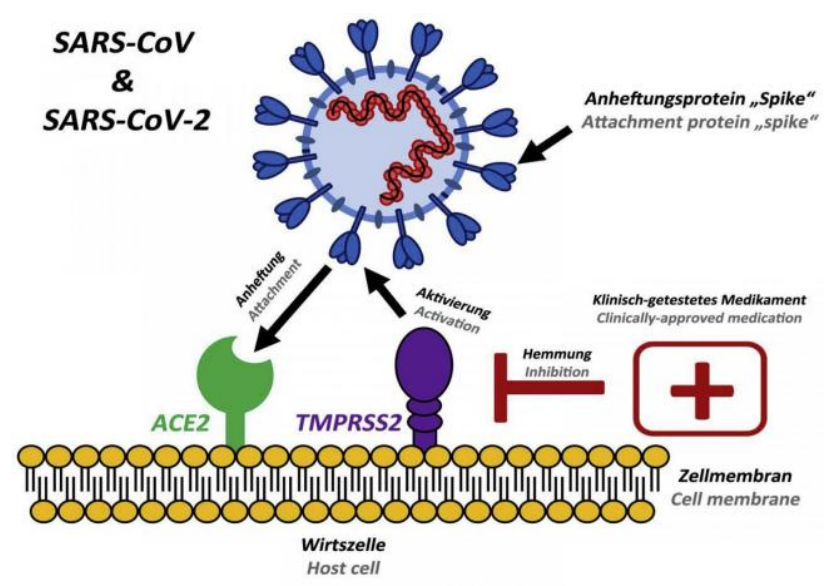

Figure 2: SARS-CoV-2 and SARS-CoV use the same cellular attachment factor (ACE2)

Adapted from: Mousavizadeh et al. J Microbiol Immunol Infect. 2020 [25]

Levels of GSCF, IP10, MCP1, and Tumor Necrosis Factor- $\alpha$ were higher in the Intensive Care Unit (hereafter ICU) patient in comparison to Non-ICU patients. An elevated level of IL-10 and IL-4 were few uncommon findings in the acute phase viral infection. Additionally, with the increase in C-Reactive Protein levels, LDH, Aspartate Transaminase, Alanine Transaminase, CK, Creatinine, erythrocyte sedimentation proportion, decreased platelet and albumin levels have also been reported [26]. As mentioned by Harapan et al., the elevated levels of cytokines and inflammatory response triggers the cytokine storm in patients, leading to an increase severity of the disease [23].

Patients with the novel coronavirus infection developed eosinopenia, increased prothrombin time, and Thrombocytopenia [27]. The chief pathogenesis of the COVID-19 virus is atypical pneumonia; detectable serum SARS-CoV-2 viral load (RNAaemia), acute respiratory distress syndrome along with ground-glass opacity in the lung, acute liver injury and acute cardiac injury [26]. ARDS is the prime cause of death with SARS-CoV-2 infection. As the virus dysregulates cytokine and inflammatory response, causing cytokine storms leading to multi-organ failure [28]. Histopathological findings of the lung showed diffuse alveolar damage with exudate in the alveolar cavity, thickening of interlobular septa giving it a honeycomb-like appearance. Lung tissues predominantly showed pulmonary edema along with hyaline membrane formation. Lung interstitium had the presence of inflammatory infiltrates - macrophages, neutrophils, and other lymphocytes, as well as Immune system dysfunction, has also been noticed in SARS-CoV2 patients, CD4 and CD8 cells were reduced, and hyperactivity was observed in patients with an increase in the severity of the disease [24].

Besides respiratory system injury, patients of SARS-CoV2 present with multi-organ injuries in the heart, liver, and brain, which correlated with different comorbidities such as Diabetes Mellitus, Hypertension, Hyperlipidemia, Ischemic Heart Disease, Coronary Artery Disease, Neoplasm, HIV and Immune System Deficiency syndromes [29]. A small cohort of patients has also had neurological complications such as a disturbed state of consciousness, headaches, and dizziness. The most common peripheral symptoms were hypogeusia and hyposmia [30]. SARS-CoV-2 infection varied from asymptomatic to atypical pneumonia, ARDS, and multiorgan dysfunction depending on the severity of the disease. Symptoms like Anorexia, Dyspnea, Fatigue, pyrexia, Cough, Headache, Dizziness, Nausea, Productive Sputum, Abdominal Pain, Myalgia, Sore Throat, Diarrhea, and Vomiting have been reported [27].

\section{Vaccines under trial for COVID-19}

There are a total of 109 vaccines that are under trial, among which 9 of them are in clinical evaluation, and 102 of them are in the pre-clinical evaluation phase. The details of the vaccines, phases of clinical trials, and the developers are depicted in Table 1. Vaccines which are in the clinical evaluation are as follows:

\section{Adenovirus type 5 vector}

ChiCTR2000031781 is under a randomized Phase 2 clinical trial. It is a placebo-controlled and double-blinded trial in adults who are above the age of 18 years. Safety and immunogenicity for the Recombinant novel Coronavirus disease vaccine (Adenovirus Vector) will be evaluated by clinical trials in healthy individuals who are aged above 18 yrs. [31]. Whereas ChiCTR2000030906 is under a single-center, open, and dose-escalation Phase 1 clinical trial in healthy individuals aged between 18-60yrs [32]. These are developed by CanSino Biological Inc. and the Beijing Institute of Biotechnology. The Canadian Centre for Vaccinology has also approved this vaccine for the Phase 1 clinical trial. The clinical trial is set to enroll approximately 100 healthy participants aged about 18 to 55 years $[33,34]$.

\section{Inactivated +alum}

NCT04352608 is under a single-center randomized trial, which is double-blinded and placebo-controlled. Phase $1 / 2$ trials are done in adults, who are in the range of 18-59 years. This study will evaluate the immunogenicity and safety. This vaccine is being developed by Sinovac Research and Development Co., Ltd. The study was started in mid-April 2020 [35]. 
Table 1: Vaccines development and clinical trials of vaccines for COVID-19

\begin{tabular}{|c|c|c|c|c|c|c|}
\hline Name of vaccine & $\begin{array}{l}\text { Type of } \\
\text { vaccine }\end{array}$ & $\begin{array}{l}\text { Vaccine } \\
\text { candidate }\end{array}$ & Target & Producing entity & $\begin{array}{c}\text { Phase of } \\
\text { trial }\end{array}$ & Country \\
\hline $\begin{array}{l}\text { Adenovirus type } 5 \text { vector } \\
\text { (ChiCTR2000031781) [31] }\end{array}$ & $\begin{array}{l}\text { Non } \\
\text { replicating } \\
\text { viral vector }\end{array}$ & $\mathrm{Ad} 5-\mathrm{nCoV}$ & S glycoprotein & $\begin{array}{l}\text { CanSina Biological Inc./Bejing } \\
\text { Institue of Biotechnology }\end{array}$ & Phase 2 & $\begin{array}{l}\text { China and } \\
\text { Canada [33] }\end{array}$ \\
\hline $\begin{array}{l}\text { mRNA-1273 } \\
(\text { NCT04283461) } \\
{[35]}\end{array}$ & $\begin{array}{l}\text { LNP- } \\
\text { encapsulated } \\
\text { mRNA }\end{array}$ & $\begin{array}{l}\text { mRNA- } \\
1273\end{array}$ & $\mathrm{~S}$ protein & Moderna & Phase 1 & United States \\
\hline $\begin{array}{l}\text { Inactivated+alum [34] } \\
\text { (NCT04352608) }\end{array}$ & Inactivated & PiCoVacc & Whole virion & $\begin{array}{lcc}\text { Sinovac Biotech Co., } & \text { Ltd } \\
\text { (Sinovac } & \text { Research } & \text { and } \\
\text { Development Co., Ltd.) } & \end{array}$ & $\begin{array}{l}\text { Phase 1/Phase } \\
2\end{array}$ & China \\
\hline $\begin{array}{l}\text { ChAdOx1 [34] } \\
(\text { NCT04324606) }\end{array}$ & $\begin{array}{l}\text { Non } \\
\text { replicating } \\
\text { viral vector }\end{array}$ & ChAdOx1 & S glycoprotein & The University of Oxford & Phase $1 / 2$ & $\begin{array}{l}\text { United } \\
\text { Kingdom }\end{array}$ \\
\hline $\begin{array}{l}3 \text { LNP-mRNA [34] } \\
\text { (NCT04368728) }\end{array}$ & RNA & BNT162 & $\mathrm{S}$ protein & BioNTech/Fosum/Pharma/Pfizer & Phase $1 / 2$ & $\begin{array}{l}\text { Germanyand } \\
\text { United states }\end{array}$ \\
\hline $\begin{array}{l}\text { DNA plasmid vaccine with } \\
\text { electroporation [36] } \\
\text { (NCT04336410) }\end{array}$ & DNA & INO-4800 & $\mathrm{S}$ protein & Inovio Pharmaceuticals & Phase 1 & $\begin{array}{lr}\text { South } & \text { Korea } \\
\text { and } & \text { United } \\
\text { States } & \end{array}$ \\
\hline $\begin{array}{l}\text { Inactivated [37] } \\
\text { (ChiCTR2000032459) }\end{array}$ & Inactivated & Not known & Whole virion & $\begin{array}{l}\text { Beijing Institute of Biological } \\
\text { Products Co., LTD. }\end{array}$ & Phase 1/ 2 & China \\
\hline
\end{tabular}

\begin{tabular}{|c|c|c|c|c|}
\hline \multicolumn{5}{|c|}{ Table 2: Drugs on Clinical Trials } \\
\hline Drugs & Mechanism of action & Sponsor & $\begin{array}{l}\text { Phases of } \\
\text { trials }\end{array}$ & Country \\
\hline $\begin{array}{l}\text { Remdesivir [41] } \\
\text { (NCT04280705) }\end{array}$ & $\begin{array}{l}\text { Halts the replication of viral genome. It } \\
\text { inhibits RNA dependent RNA polymerase } \\
\text { enzyme }\end{array}$ & $\begin{array}{l}\text { National Institute of } \\
\text { Allergy and Infectious } \\
\text { Diseases (NIAID) }\end{array}$ & Phase 3 & $\begin{array}{l}\text { United states of } \\
\text { America }\end{array}$ \\
\hline $\begin{array}{l}\text { Lopinavir/Ritonavir and } \\
\text { interferon beta-1b } \\
\text { [41] } \\
\text { (NCT04276688) }\end{array}$ & $\begin{array}{l}\text { IV protease inhibitors as well as inhibit } \\
\text { coronaviral } 3 \mathrm{CL} 1 \text { protease. }\end{array}$ & $\begin{array}{l}\text { The University of Hong } \\
\text { Kong }\end{array}$ & $\begin{array}{l}\text { Phase } 2 \\
\text { completed }\end{array}$ & Hongkong \\
\hline $\begin{array}{l}\text { Hydroxychloroquine } \\
\text { (NCT04315896) } \\
{[41]}\end{array}$ & $\begin{array}{l}\text { Blocks viral infection by increasing } \\
\text { endosomal } \mathrm{pH} \text { required for membrane fusion } \\
\text { between the virus and the host cell. }\end{array}$ & $\begin{array}{l}\text { National Institute of } \\
\text { Respiratory Diseases, } \\
\text { Mexico }\end{array}$ & Phase 3 & Mexico \\
\hline $\begin{array}{l}\text { Hydroxychloroquine/ } \\
\text { chloroquine } \\
\text { (NCT04303507) } \\
{[41]}\end{array}$ & $\begin{array}{l}\text { Blocks viral infection by increasing } \\
\text { endosomal } \mathrm{pH} \text { required for membrane fusion } \\
\text { between the virus and the host cell. }\end{array}$ & University of Oxford & Not applicable & United Kingdom \\
\hline
\end{tabular}

\section{3. mRNA-1273}

It is under the open-label phase 1 trial in males and nonpregnant females above the age of 18 years, who are healthy and qualify in all the eligibility criteria. This encapsulated mRNA-based vaccine is a novel lipid nanoparticle (LNP) encodes for a prefusion stabilized spike (S) protein, covering the full length of the protein. The clinical trial is dose ranged and will assess the safety, reactogenicity and immunogenicity of it. It is being manufactured by ModernaTX, Inc. This study started in mid of March 2020 [35]. Recently on Moderna's vaccine is currently in phase I clinical trial, it has shown that it produced protective antibodies in a small group of healthy volunteers [36]. 


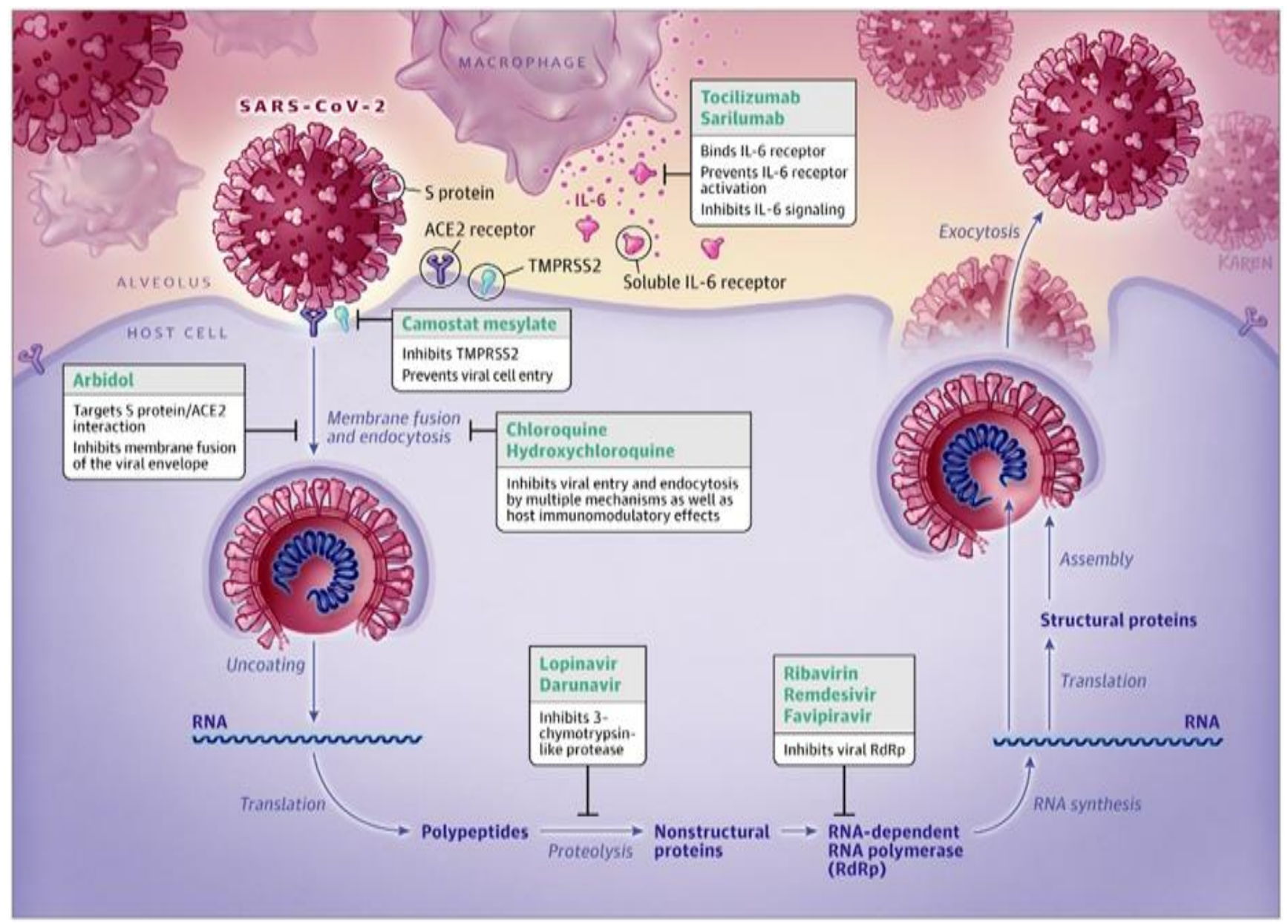

Figure 3: Potential targets of the COVID-19 Drugs

Adapted from: Sanders et al. Pharmacologic Treatments for Coronavirus Disease 2019 (COVID-19): A Review. JAMA. 2020 [42].

\section{ChAdOx1}

NCT04324606 It is under Phase 1/2 single-blinded, randomized, multi-center trial, which will determine the immunogenicity \& safety along with its efficacy. Healthy adult candidates in UK healthy volunteered for trials, aged between 18-55 years. This vaccine is being developed by University of Oxford. The study started at the end of April 2020 [35].

\section{3 LNP-mRNA}

Observer-blind clinical trials under randomized Phase 1/2 are being conducted, which is placebo-controlled. The candidate-selection and dose-finding are done in healthy adults. To compare tolerability, viral immunogenicity, and safety with four different SARS-CoV-2RNA vaccines, three age groups were considered: $18-55$ years, $65-85$ years, and 18-85 years; this would also evaluate its efficacy. This vaccine is being developed by BioNTech/Fosun Pharma/Pfizer. The study started in April 2020 [35].

\section{DNA plasmid vaccine with electroporation (INO- 4800)}

Open-label (Phase 1), It is under trial is done to evaluate the immunological profile of INO-4800, it was administered by injection via intradermal route followed by electroporation (EP) device in adult volunteers which would also help in analyzing its safety and tolerability. The study was started in April 2020 [37].

\section{Inactivated}

ChiCTR2000032459 is under a randomized trial which double-blinded in Phase1/2. This placebo-parallel controlled trial will evaluate its immunogenicity of inactivated $\mathrm{nCoV}$ in a healthy population aged three years and older. It is being developed by the Beijing Institute of Biological Products/Sinopharm [38]. 


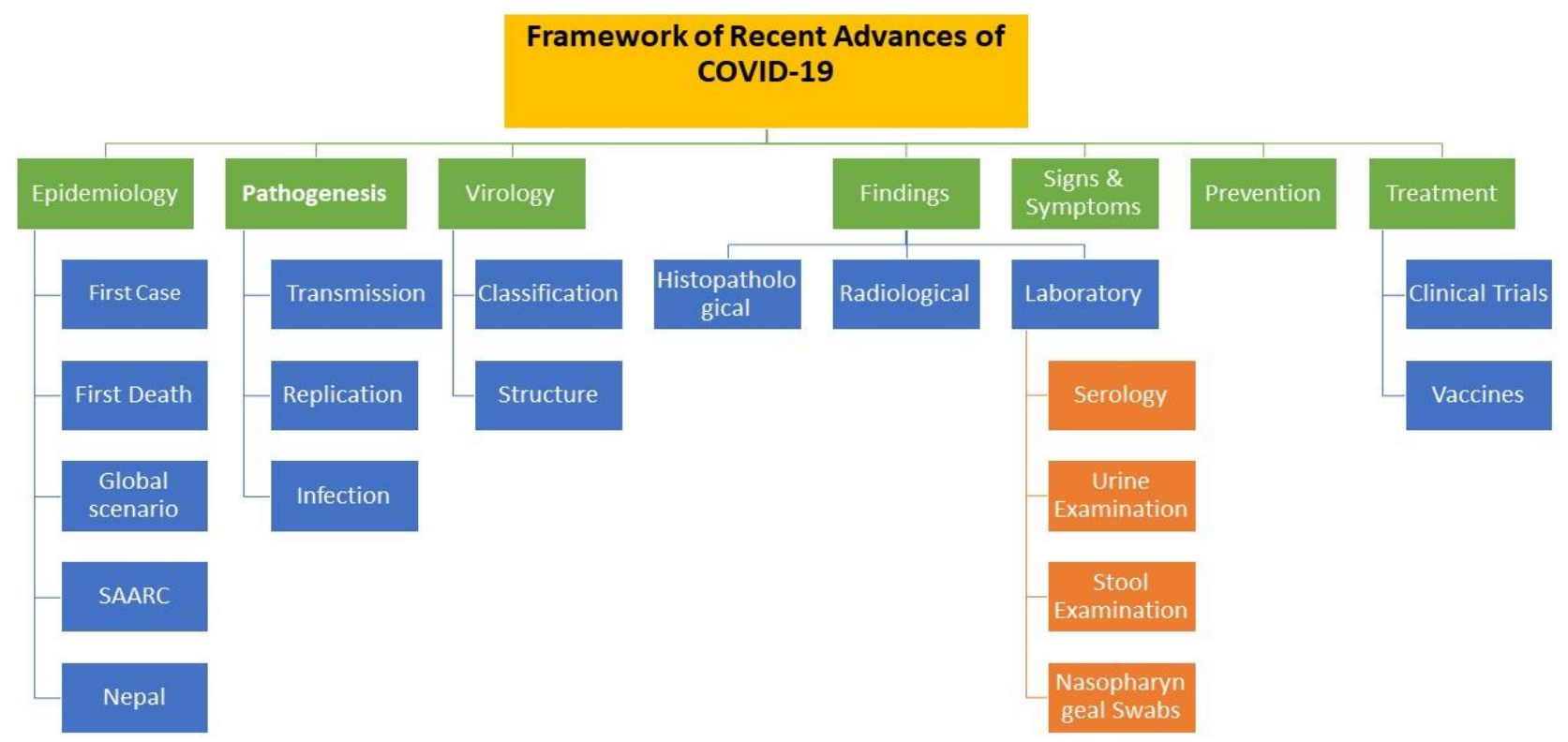

Figure 4: Framework of COVID-19

\section{Clinical Trials: Treatment and prophylaxis}

Currently, there is no drug available and found to be competent for the treatment and prophylaxis of COVID19. Pharmaceutical companies of several countries and institutions around the world have already registered for the clinical trials of various antimalarials antivirals, antiinflammatory and immunomodulation treatment therapies. Several other trials are currently already active and in progress [39]. At present, there are approximately more than 300 clinical trials underway. None of the drugs are approved for prophylaxis of COVID-19, but according to the Indian medical council, published in The Lancet, hydroxychloroquine or chloroquine has been recommended to be administered to the health care workers who are in direct contact with COVID-19 patients and for asymptomatic household contacts of confirmed cases [40].

An international clinical trial is known as "Solidarity" (ISRCTN83971151) [41] has been initiated by WHO to develop an effective treatment for COVID-19. The main aim of the clinical trial is to rapidly find the effect of drugs on disease progression and survival. It is an openlabel Phase III randomized multicounty clinical trial. As of the 21st April 2020, to find effective therapeutics, over 100 countries are working jointly through this clinical trial. The potential targets of the drugs are shown in Figure 3. The details of the drugs, mechanism of action, developer, phases of clinical trials, and the country is depicted in Table 2.

Health systems and governments alike are facing unprecedented pressure as the death tolls are rising on a daily basis [43]. Numerous countries have declared states of emergency and have invoked national restrictions of movement under various acts such as the Public Health (Control of Disease) Act 1984 (England) [44]. Till this current point in time the mainstay of controlling the spread of the disease has been via social distancing, the isolation of confirmed cases which have then been followed up by contact tracing [45].

\section{Conclusion}

Despite the countless scientific advances and state of the art facilities and equipment at our disposal, researchers are somehow at a shortcoming for finding a permanent solution to this current crisis. It is hence invariably essential to promote research in this field of study and to find an appropriate solution to the virus so as to allow individuals all around the globe to lead a secure and healthy life in the future.

\section{Abbreviations}

Acute Respiratory Distress Syndrome (ARDS), Basic Reproductive number (Ro), Middle East Respiratory Syndrome (MERS), RNA-dependent RNA polymerase (RdRp), Severe Acute Respiratory Syndrome (SARS), The South Asian Association for Regional Cooperation (SAARC), World Health Organization (WHO)

\section{Acknowledgments}

We extend our intense gratitude to Chairman Mr. RPN Singh and Prof. Namrata Chhabra, Principal In-charge, SSR Medical College, Mauritius, for providing us with enormous support and guidance to conduct the research study effectively. 


\section{Authors' contribution}

a. Study planning: IB

b. Manuscript writing: IB, PM, AS, AK, JR

c. Manuscript revision: IB, PM, AS, AK, JR

d. Final approval: IB, PM, AS, AK, JR

e. Agreement to be accountable for all aspects of the work:

IB, PM, AS, AK, JR

\section{Funding}

There was no funding for this work.

\section{Availability of data and materials}

All data and materials available as part of the article, and no additional source data are required.

\section{Competing interests}

There is no conflict of interest for any author of this manuscript.

\section{Publisher's Note}

NHRS remains neutral with regard to jurisdictional claims in published maps and institutional affiliations.

The publisher shall not be legally responsible for any types of loss, actions, claims, proceedings, demand or costs or damages whatsoever or howsoever caused arising directly or indirectly in connection with or arising out of the use of this material.

\section{Author information}

${ }^{1}$ Dr Indrajit Banerjee, Associate Professor, Department of Pharmacology, Sir Seewoosagur Ramgoolam Medical College, Mauritius ORCID

${ }^{2}$ Poornasha Mohabeer, ORCID

${ }^{3}$ Ananya Shukla, ORCID

${ }^{4}$ Abhishek Kashyap, ORCID

${ }^{5} \mathrm{Mr}$. Jared Robinson, $\underline{\text { ORCID }}$

2-52nd Professional medical student, Sir Seewoosagur Ramgoolam Medical College, Mauritius

\section{References}

1. Wan Y, Shang J, Graham R, Baric RS, Li F. Receptor Recognition by the Novel Coronavirus from Wuhan: an Analysis Based on Decade-Long Structural Studies of SARS Coronavirus. J Virol. 2020;94(7):e00127-20. https://doi.org/10.1128/JVI.00127-20

2. Anastassopoulou C, Russo L, Tsakris A, Siettos C. Data-based analysis, modelling and forecasting of the COVID-19 outbreak. PLoS One. 2020;15(3):e0230405. https://doi.org/10.1371/journal.pone.0230405

3. Chen N, Zhou M, Dong X, Qu J, Gong F, Han Y, et al. Epidemiological and clinical characteristics of 99 cases of 2019 novel coronavirus pneumonia in
Wuhan, China: a descriptive study. Lancet. 2020;395(10223):507-513.

https://doi.org/10.1016/S0140-6736(20)30211-7

4. Lai CC, Shih TP, Ko WC, Tang HJ, Hsueh PR. Severe acute respiratory syndrome coronavirus 2 (SARS-CoV-2) and coronavirus disease-2019 (COVID-19): The epidemic and the challenges. Int J Antimicrob Agents. 2020;55(3):105924.

https://doi.org/10.1016/j.ijantimicag.2020.105924

5. Wang W, Tang J, Wei F. Updated understanding of the outbreak of 2019 novel coronavirus (2019$\mathrm{nCoV}$ ) in Wuhan, China. J Med Virol. 2020;92(4):441-447.

https://doi.org/10.1002/jmv.25689

6. WHO Coronavirus Disease (COVID-19) Dashboard. Available from: https://covid19.who.int/ (Accessed on 29.05.2020)

7. World Health Organization. Coronavirus [Homepage of the World Health Organization] [online2020] [Accessed on 29/05/2020] Available from: https://www.who.int/

8. Most COVID-19 patients in Nepal are males under 30. [Accessed on 29/05/2020] Available from:

URL:

https://myrepublica.nagariknetwork.com/news/most -of-the-covid-19-patients-under-30-overwhelmingmales-total-tally-hits-457/

9. Strochlic N. U.S. coronavirus deaths now surpass fatalities in the Vietnam War. National Geographic. [Accessed on 16/05/2020] Available from: URL: https://www.nationalgeographic.com/history/2020/0 4/coronavirus-death-toll-vietnam-war-cvd/

10. Lu R, Zhao X, Li J, Niu P, Yang B, Wu H, et al. Genomic characterisation and epidemiology of 2019 novel coronavirus: implications for virus origins and receptor binding. Lancet. 2020;395(10224):565-74. https://doi.org/10.1016/S0140-6736(20)30251-8

11. Li X, Geng M, Peng Y, Meng L, Lu S. Molecular immune pathogenesis and diagnosis of COVID-19. J Pharm Anal. 2020;10(2):102-8. https://doi.org/10.1016/j.jpha.2020.03.001

12. Decaro N, Lorusso A. Novel human coronavirus (SARS-CoV-2): A lesson from animal coronaviruses. Vet Microbiol. 2020;244:108693. https://doi.org/10.1016/j.vetmic.2020.108693

13. Petrosillo N, Viceconte G, Ergonul O, Ippolito G, Petersen E. COVID-19, SARS and MERS: are they closely related? [published online ahead of print, 2020 Mar 28]. Clin Microbiol Infect. 2020;S1198743X(20)30171-3.

14. Liu Y, Gayle AA, Wilder-Smith A, Rocklöv J. The reproductive number of COVID-19 is higher compared to SARS coronavirus. J Travel Med. 2020;27(2):taaa021. https://doi.org/10.1093/jtm/taaa021 
15. Lam TT, Jia Na, Zhang YW, Shum MH, Jiang JF Zhu HC, et al. Identifying SARS-CoV-2 related coronaviruses in Malayan pangolins [published online ahead of print, 2020 Mar 26]. Nature. 2020; https://doi.org/10.1038/s41586-020-2169-0

16. Li Q, Guan X, Wu P, Wang X, Zhou L, Tong Y, et al. Early Transmission Dynamics in Wuhan, China, of Novel Coronavirus-Infected Pneumonia. N Engl J Med. 2020;382(13):1199-207.

17. Lai MM, Cavanagh D. The molecular biology of coronaviruses. Adv Virus Res. 1997;48:1-100. https://doi.org/10.1016/S0065-3527(08)60286-9

18. Walls AC, Park YJ, Tortorici MA, Wall A, McGuire AT, Veesler D. Structure, Function, and Antigenicity of the SARS-CoV-2 Spike Glycoprotein. Cell. 2020;181(2):281-292.e6. https://doi.org/10.1016/j.cell.2020.02.058

19. Schematic of a coronavirus - this new virus probably looks a lot like this. Biowiki: [Accessed on 21.05.2020] Available from URL: http://ruleof6ix.fieldofscience.com/2012/09/a-newcoronavirus-should-you-care.html

20. Shereen MA, Khan S, Kazmi A, Bashir N, Siddique R. COVID-19 infection: Origin, transmission, and characteristics of human coronaviruses. J Adv Res. 2020;24:91-98. https://doi.org/10.1016/i.jare.2020.03.005

21. Laboratory testing for 2019 novel coronavirus (2019-nCoV) in suspected human cases [Internet]. Who.int. 2020 [cited 20 May 2020]. Available from: https://www.who.int/publications-detail/laboratorytesting-for-2019-novel-coronavirus-in-suspectedhuman-cases-20200117

22. Hamid S, Mir MY, Rohela GK. Novel coronavirus disease (COVID-19): a pandemic (epidemiology, pathogenesis and potential therapeutics). New Microbes New Infect. 2020;35:100679. Published 2020 Apr 14. https://doi.org/10.1016/j.nmni.2020.100679

23. Harapan H, Itoh N, Yufika A, Winardi W, Keam S, Te H, et al. Coronavirus disease 2019 (COVID-19): A literature review. J Infect Public Health. 2020;13(5):667-673.

https://doi.org/10.1016/j.jiph.2020.03.019

24. Jin Y, Yang H, Ji W, Wu W, Chen S, Zhang W, et al. Virology, Epidemiology, Pathogenesis, and Control of COVID-19. Viruses. 2020;12(4):E372. https://doi.org/10.3390/v12040372

25. Mousavizadeh L, Ghasemi S. Genotype and phenotype of COVID-19: Their roles in pathogenesis [published online ahead of print, 2020 Mar 31]. J Microbiol Immunol Infect. 2020 https://doi.org/10.1016/j.jmii.2020.03.022

26. Rothan HA, Byrareddy SN. The epidemiology and pathogenesis of coronavirus disease (COVID-19) outbreak. J Autoimmun. 2020;109:102433. https://doi.org/10.1016/j.jaut.2020.102433

27. Siordia JA Jr. Epidemiology and clinical features of COVID-19: A review of current literature [published online ahead of print, 2020 Apr 10]. J Clin Virol. 2020;127:104357. https://doi.org/10.1016/j.jcv.2020.104357

28. Ye Q, Wang B, Mao J. The pathogenesis and treatment of the 'Cytokine Storm' in COVID-19. J Infect. 2020;80(6):607-13. https://doi.org/10.1016/j.jinf.2020.03.037

29. Huang C, Wang Y, Li X, Ren L, Zhao J, Hu Y, et al. Clinical features of patients infected with 2019 novel coronavirus in Wuhan, China. Lancet. 2020;395(10223):497-506. https://doi.org/10.1016/S0140-6736(20)30183-5

30. Carod-Artal FJ. Neurological complications of coronavirus and COVID-19. Complicaciones neurológicas por coronavirus y COVID-19. Rev Neurol. 2020;70(9):311-22.

https://doi.org/10.33588/rn.7009.2020179

31. Randomized, double-blind, placebo-controlled phase II clinical trial of recombinant new coronavirus (2019-nCOV) vaccine (adenovirus vector) [Accessed on 20/05/2020] Available from http://www.chictr.org.cn/showproj.aspx?proj=5200 $\underline{6}$

32. Phase I clinical trial of recombinant new coronavirus (2019-COV) vaccine (adenovirus vector) [Accessed on 20/05/2020]. Available from: URL:

http://www.chictr.org.cn/showproj.aspx?proj=5115 4

33. Health Canada approves first Covid-19 vaccine trials. [cited 2020 May 18] Available from: URL: https://www.clinicaltrialsarena.com/news/canadacovid-19-vaccine-trials/ [Accessed on 21/05/2020]

34. Safety and Immunogenicity Study of 2019-nCoV Vaccine (mRNA-1273) for Prophylaxis of SARSCoV-2 Infection (COVID- 19) [Accessed on 20/05/2020] Available from: URL: https://clinicaltrials.gov/ct2/show/NCT04283461?te $\underline{\mathrm{rm}=\mathrm{NCT} 04283461 \& \text { cond }=\text { covid }+19 \& \mathrm{draw}=2 \& \mathrm{ran}}$ $\underline{\mathrm{k}=1}$

35. Moderna's Work on a COVID-19 Vaccine Candidate. [Accessed on 20/05/2020] Available from: URL: https://www.modernatx.com/modernaswork-potential-vaccine-against-covid-19

36. NIH clinical trial of investigational vaccine for COVID-19 begins. [Accessed on 20/05/2020] Available from: URL: https://www.nih.gov/newsevents/news-releases/nih-clinical-trialinvestigational-vaccine-covid-19-begins

37. A phase I/II clinical trial for inactivated novel coronavirus (2019-CoV) vaccine (Vero cells) [Accessed on 20/05/2020] Available from: URL: 
http://www.chictr.org.cn/showproj.aspx?proj=5300 $\underline{3}$

38. Draft landscape of COVID-19 candidate vaccines. [Accessed on 20/05/2020] Available from URL: https://www.who.int/who-documents-detail/draftlandscape-of-covid-19-candidate-vaccines

39. Şimşek Yavuz S, Ünal S. Antiviral treatment of COVID-19. Turk J Med Sci. 2020;50(SI1):611-619. https://doi.org/10.3906/sag-2004-145

40. Rathi S, Ish P, Kalantri A, Kalantri S. Hydroxychloroquine prophylaxis for COVID-19 contacts in India [published online ahead of print, 2020 Apr 17]. Lancet Infect Dis. 2020;S14733099(20)30313-3.

https://doi.org/10.1016/S1473-3099(20)30313-3

41. "Solidarity" clinical trial for COVID-19 treatments [Accessed on 15/05/2020] Available from: URL: https://www.who.int/emergencies/diseases/novelcoronavirus-2019/global-research-on-novelcoronavirus-2019-ncov/solidarity-clinical-trial-forcovid-19-treatments

42. Sanders JM, Monogue ML, Jodlowski TZ, Cutrell JB. Pharmacologic Treatments for Coronavirus Disease 2019 (COVID-19): A Review. JAMA. 2020;10.1001/jama.2020.6019. https://doi.org/10.1001/jama.2020.6019

43. Van Lancker W, Parolin Z. COVID-19, school closures, and child poverty: a social crisis in the making. Lancet Public Health. 2020;5(5):e243-e244. https://doi.org/10.1016/S2468-2667(20)30084-0

44. Joob B, Wiwanitkit V. COVID-19, School Closings, and Weight Gain. Obesity. 2020 6;28(6):1006.

https://doi.org/10.1002/oby.22825

45. Cheng HY, Jian SW, Liu DP, Ng TC, Huang WT, Lin HH, et al. Contact Tracing Assessment of COVID-19 Transmission Dynamics in Taiwan and Risk at Different Exposure Periods Before and After Symptom Onset [published online ahead of print, 2020 May 1]. JAMA Intern Med. 2020;e202020.

https://doi.org/10.1001/jamainternmed.2020.2020 